\title{
EDUKASI CARA MENJADI JUMANTIK MANDIRI UNTUK MENCEGAH DBD DI TENGAH PANDEMI COVID-19 PADA KADER POSYANDU DI DUSUN JETIS, BAKUNGAN, KARANGDOWO, KLATEN
}

\section{EDUCATION OF HOW TO BECOME INDEPENDENT JUMANTIK TO PREVENT DHF DURING PANDEMI COVID-19 TO POSYANDU MEMBERS IN JETIS, BAKUNGAN, KARANGDOWO, KLATEN}

\author{
Aisya Kusumawati ${ }^{1)^{*}}$, Ajeng Kusumaning $\mathrm{Ayu}^{2}{ }^{2}$, Anggita Mutiara Saputri ${ }^{3)}$, Priska \\ Bintang Putriadi $^{4)}$, Muhammad Taufiq Qurrohman', Noviana Dewi ${ }^{6)}$ \\ ${ }^{1)}$ D-III TLM, STIKES Nasional. email: aisyakusumawati21@gmail.com \\ ${ }^{2)}$ D-III TLM, STIKES Nasional. email: ajeng.kusumaning6308cq@ gmail.com \\ ${ }^{3)}$ D-III TLM, STIKES Nasional. email: anggita.mutiaras2408@ gmail.com \\ ${ }^{4)}$ D-III TLM, STIKES Nasional. email: priskabintangp@ gmail.com \\ ${ }^{5)}$ D-III TLM, STIKES Nasional. email: m.taufiqqurrohman@stikesnas.ac.id \\ ${ }^{6)}$ D-III TLM STIKESNasional. email: viana072@gmail.com
}

\begin{abstract}
ABSTRAK
Penyakit demam berdarah dengue (DBD) merupakan salah satu masalah kesehatan masyarakat di Indonesia yang jumlah penderitanya cenderung meningkat dan penyebarannya semakin luas. Penyakit DBD merupakan penyakit menular yang terutama menyerang anakanak. Penyakit DBD mempunyai perjalanan yang sangat cepat dan sering menjadi fatal karena banyak pasien yang meninggal akibat penanganannya yang terlambat. Kegiatan penyuluhan ini bertujuan untuk mengedukasi warga di Dusun Jetis, Bakungan tentang pencegahan Demam Berdarah Dengue. Dari hasil kegiatan, peserta bisa memahami materi dengan baik dan mereka merasa puas dengan materi yang telah disampaikan.
\end{abstract}

Kata kunci: DBD, Imunitas, Pencegahan

\section{ABSTRACT}

Dengue hemorrhagic fever (DHF) is a public health problem in Indonesia where the number of sufferers tends to increase and its spread is increasingly widespread. DHF is a contagious disease that mainly affects children. DHF, which travels very quickly and often becomes fatal because many patients die due to late treatment. This outreach activity aims to educate residents in Jetis , Bakungan about preventing Dengue Hemorrhagic Fever. From the results of the activity, participants can understand the material well and they feel satisfied with the material that has been delivered.

Keywords: DBD, Immunity, Prevention

\section{PENDAHULUAN}

Demam Berdarah Dengue (DBD) merupakan penyakit yang banyak ditemukan di sebagian besar wilayah tropis dan subtropis, terutama di Asia Tenggara, Amerika Tengah, Amerika dan Karibia. Host alami DBD adalah manusia, agennya adalah virus dengue yang termasuk ke dalam family Flaviridae dan genus Flavivirus. Ditularkan ke manusia melalui gigitan nyamuk yang terinfeksi, khususnya nyamuk Aedes aegypti dan Aedes albopictus yang terdapat hampir di seluruh pelosok Indonesia, kecuali di tempat yang memiliki ketinggian lebih dari 1000 meter di atas permukaan laut. Penyakit DBD banyak dijumpai terutama di daerah tropis dan sering menimbulkan kejadian luar biasa (KLB). ( Farasari, 2018). Penyebaran dengue dipengaruhi faktor iklim seperti curah hujan, suhu, dan kelembaban. Kelangsungan 
hidup nyamuk akan lebih lama bila tingkat kelembaban tinggi, seperti selama musim hujan (Nazri, dkk, 2013).

Penyakit DBD masih merupakan permasalahan serius di provinsi Jawa Tengah, terbukti 35 kabupaten/kota sudah pernah terjangkit penyakit DBD di provinsi Jawa Tengah pada tahun 2012 sebesar 19,29/100.000 penduduk, angka kesakitan/ Insidence Rate (IR) DBD di provinsi Jawa Tengah pada tahun 2013 sebesar 43,53/100.000 penduduk, meningkat bila dibandingkan tahun 2012 dan sudah melampaui target nasional, yaitu $<20 / 100.000$ penduduk. (Farasari, 2018).

Curah hujan dapat menambah jumlah tempat perkembangbiakan vektor (breeding places) atau dapat pula menghilangkan tempat perindukan. Curah hujan dapat juga berpengaruh terhadap suhu dan kelembaban nisbi udara. Menurut Cahyati (2006) bahwa curah hujan $140 \mathrm{~mm} /$ minggu dapat menghambat berkembangbiaknya nyamuk. Curah hujan yang lebat menyebabkan bersihnya tempat perindukan vektor oleh karena hanyut terbawa aliran air yang menyebabkan matinya larva/jentik nyamuk. Suhu mempengaruhi menetasnya larva Aedes aegypti menjadi pupa dan dewasa. Suhu yang terbaik menetaskan larva menjadi dewasa antara suhu $26^{\circ} \mathrm{C}-32^{\circ} \mathrm{C}$, bila suhu terlalu ekstrim di bawah $26{ }^{\circ} \mathrm{C}$ atau di atas $32{ }^{\circ} \mathrm{C}$ maka daya penetasan larva menjadi dewasa akan menurun (Nisa, 2018).

Angka kematian pada Penyakit Demam Berdarah Dengue (DBD) yang tidak segera mendapat perawatan mencapai 50\%, akan tetapi angka kematian tersebut dapat diminimalkan mencapai 5\% bahkan bisa mencapai 3\% atau lebih rendah lagi dengan tindakan atau pengobatan cepat. Hingga saat ini diagnosis penyakit Demam Berdarah Dengue (DBD) berdasarkan atas gejala klinis dan pemeriksaan laboratorium darah untuk mengetahui gejala syok (Pongsilurang, dkk, 2015).

\section{METODE PELAKSANAAN KEGIATAN}

Metode yang digunakan dalam PKMD ini yakni dengan cara:

1. Pengerjaan soal pretes mengenai pengertian DBD dan pencegahan, hubungan stress dan imunitas, dan juga materi tentang pemantauan jentik mandiri yang dikerjakan oleh seluruh peserta dengan didampingi panitia.

2. Penyuluhan dilakukan secara daring dan luring, yang mana materi yang dijelaskan mengenai DBD, hubungan stress dengan imunitas, dan cara pemantauan jentik secara mandiri.

3. Tanya jawab dan diskusi antara peserta dan pemberi materi.

4. Postes mengenai pengertian DBD dan pecegahan, hubungan stress dan imunitas, dan juga materi tentang pemantauan jentik mandiri.

5. Pemberian tanaman rosemary kepada seluruh peserta.

6. Pemantauan jentik ke rumah peserta, serta edukasi tentang pemberian larvasida. 


\section{HASIL DAN PEMBAHASAN}

Kegiatan pengabdian kepada masyarakat berhasil dengan dihadiri $80 \%$ peserta undangan yaitu 8 peserta dari 10 undangan seperti yang tersaji pada tabel berikut.

\section{Data Peserta}

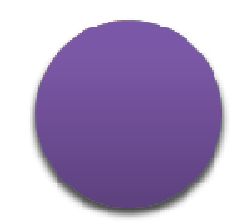

n Hadir a Iidak Hadir

Hasil analisis nilai pre test dan post test menggunakan SPSS dengan uji Paired Sample Test yang mengalami perubahan yang signifikan ditunjukkan dengan nilai signifikansi (2-tailed) pada kuesioner pengetahuan tentang DBD adalah 0,000 menunjukkan perbedaan yang signifikan seperti tersaji di tabel berikut.

\begin{tabular}{lccc}
\hline & Mean & $\begin{array}{c}\text { Std. } \\
\text { deviation }\end{array}$ & $\begin{array}{c}\text { Sig.(2- } \\
\text { tailed }\end{array}$ \\
\hline Pretest \& & $-25,000$ & 9,258 & 0,000 \\
Postest & & & \\
\hline
\end{tabular}

Data nilai post test dan pre test diuji dengan SPSS dengan menggunakan uji Paired sample test didapatkan hasil perbedaan yang signifikan untuk nilai pre test dibandingkan nilai post test, seperti yang tersaji pada tabel berikut untuk kuesioner pengetahuan tentang DBD.

Pada tabel "Paired Samples Statistic" terlihat statistik deskriptif berupa rata-rata dan standart deviasi pre-test dan post-test. Rata-rata pre-test adalah 72,50 dengan standart deviasi 10,351. Pada post-test didapat rata-ratanya dalah 97,50 dengan standart deviasi 7,071.Uji t berpasangan dapat dilihat pada table "Paired Samples Test", terlihat dari nilai mean perbedaan antara pre-test dan post-test dalah 25.000 dengan standart deviasi 9.258. Perbedaan ini diuji dengan uji t berpasangan menghasilkan nilai p yang dapat dilihat pada kolom "Sig (2-tailed)". Didapatkan nilai $\mathrm{p}=0.000$ $(0,0001)$ maka dapat disimpulkan ada perbedaan yang signifikan antara hasil pretest dan hasil post-test.

\begin{tabular}{ccccc}
\hline & Mean & $N$ & $\begin{array}{c}\text { Standart } \\
\text { deviation }\end{array}$ & $\begin{array}{c}\text { Std. } \\
\text { Error } \\
\text { Mean }\end{array}$ \\
\hline Pretest & 72.50 & 8 & 10.351 & 3.660 \\
\hline Postest & 97.50 & 8 & 7.071 & 2.500
\end{tabular}

\begin{tabular}{llcl}
\hline & $N$ & Correlation & Sig \\
\hline Pretest \& & 8 & 0.488 & 0,000
\end{tabular}

Postest

\begin{tabular}{lccc}
\hline & \multicolumn{2}{c}{$\begin{array}{c}\text { 95\% Confidence } \\
\text { Interval of the } \\
\end{array}$} & \multirow{2}{*}{$t$} \\
& difference & & \\
\cline { 2 - 3 } & Lower & Upper & \\
\hline Pretest \& & -32.740 & -17.260 & -7.638 \\
Postest & & & \\
\hline
\end{tabular}

Selain pretes dan postes, peserta juga diminta untuk mengisi angket kuisioner. Berdasarkan hasil rekap Angket Kepuasan yang dilakukan didapatkan nilai rata-rata 4,55 atau dapat dikatakan Baik. Jika dikategorikan berdasarkan kategorisasi nilai skala penyelengaraan penyuluhan di Dusun Jetis, Bakungan, Karangdowo, Klaten dapat dikategorikan Memuasakan. Saat acara 
berlangsung, peserta sangat antusias dengan materi yang disampaikan. Ini ditunjukkan dengan banyaknya peserta yang bertanya tentang bagaimana upaya pencegahan dan penanganan dini jika ada kasus DBD di desa Jetis. Karena saat ini sedang terjadi pandemi COVID-19, peserta juga menanyakan tentang imunitas, mengingat penyebab DBD salah satunya sistem imun yang menurun. Imunitas adalah hal penting yang harus tetap dijaga agar tidak mudah terserang penyakit, ditambah memasuki musim penghujan, DBD bisa saja terjadi, maka dari itu sistem kekebalan tubuh harus selalu ditingkatkan. Cara lain yang bisa dilakukan untuk mencegah DBD yakni dengan pemantauan jentik. Salah satu upaya untuk mengurangi jentik nyamuk adalah dengan pemantuan jentik nyamuk secara berkala. Juru Pemantau Jentik (Jumantik) adalah orang yang melakukan pemeriksaan jentik secara berkala dan terus menerus serta menggerakan dan mengajak masyarakat seluruhnya untuk berpartisipasi aktif mencegah penyakit DBD (Mubarokah, 2013). Penelitian yang dilakukan oleh (Efendy, 2010) terhadap masyarakat sebagai pemantau jentik didapatkan bahwa ada hubungan yang bermakna antara tingkat pengetahuan masyarakat sebelum dan sesudah diberikan pendidikan kesehatan. Angka bebas jentik yang semula $7 \%$ dapat ditingkatkan menjadi 96\% pada akhir pelatihan. Angka bebas jentik yang meningkat dapat memutus siklus hidup nyamuk Aedes aegypti sehingga kepadatan populasi serta regenerasi nyamuk akan berkurang. (Diba \& Farkhan. 2017).

Di situasi pandemi COVID-19 seperti ini, jumantik mandiri adalah cara yang paling efektif yang bisa diterapkan untuk mencegah DBD. Cara menjadi jumantik mandiri yaitu:

1. Periksalah bak mandi/WC, tempayan, drum dan tempat-tempat penampungan air lainnya.

2. Jika tidak terlihat adanya jentik tunggu sampai kira-kira satu menit, jika ada jentik pasti akan muncul ke permukaan air untuk bernafas.

3. Gunakan senter apabila wadah air tersebut terlalu dalam dan gelap.

4. Periksa juga tempat-tempat berpotensi menjadi tempat perkembangbiakan nyamuk misalnya vas bunga, tempat minum burung, kaleng-kaleng bekas, botol plastik, ban bekas, tatakan pot bunga, tatakan dispenser dan lain-lain.

5. Tempat lain di sekitar rumah yaitu talang/saluran air yang terbuka/tidak lancar, lubang-lubang pada potongan bambu atau pohon lainnya. (Dirjen Pencegahan dan Pengendalian Penyakit, 2016).

Keberhasilan usaha pencegahan demam berdarah ini sangat ditentukan oleh kekompakan dan kesadaran masyarakat secara keseluruhan. Karena nyamuk sebagai vektor penyakit mempunyai mobilitas yang tinggi untuk berpindah tempat dan menyebarkan penyakit. Untuk itu dari kegiatan ini diharapkan para peserta dapat mensosialisasikan dan memperbanyak tanaman anti nyamuk di daerah masingmasingdi lingkungan tempat tinggal mereka nantinya.

Penggunaan tanaman anti nyamuk secara menyeluruh dan terintegrasi merupakan salah 
satu metode yang berpotensi dalam upaya mengurangan penyakit demam berdarah. Memiliki cara yang lebih ramah lingkungan dan sangat murah baik dari segi biaya maupun aplikasinya. Cara tersebut adalah dengan menanam tanaman yang tidak disukai oleh nyamuk, biasa dikenal dengan tanaman hidup pengusir nyamuk atau anti-nyamuk. Tanaman ini dalam kondisi hidup mampu menghalau nyamuk. (Zen \& Noor, 2016). Beberapa jenis tanaman yang dapat dikelompokkan sebagai tanaman pengusir nyamuk diantaranya Zodia (Evodia suaveolens), Serai (Andropogon nardus L.), Lavender (Lavandula angustifolia), geranium (Pelargonium citrosa), Rosemary. Tanaman tanaman ini terbukti mengandung zat aktif yang sangat dihindari serangga. Contohnya serai (Andropogon nardus L.) mengandung zat aktif sitronelol dan geraniol yang tidak disukai serangga. Kemudian tanaman Zodia (Evodia suaveolens) mengandung senyawa Linalool yang berfungsi sebagai pengusir nyamuk (Rahmatullah, 2018).

Selain menanam tanaman anti nyamuk sebagai upaya pencegahan secara biologis, memelihara ikan juga bisa menjadi upaya untuk membasmi jentik nyamuk. Beberapa jenis ikan yang dapat berperan sebagai predator larva nyamuk adalah ikan cupang (Beta splendens), ikan guppy (Poecelia reticulatta), ikan larvavarous (Gambusia affinis), ikan kepala timah (Panchax panchax), ikan golden, ikan melem dan ikan sepat. Jenis-jenis ikan tersebut merupakan ikan yang hidup di air tawar, air tergenang, air dengan temperature rendah atau air hangat, air jernih maupun berlumpur. Ikan larvavarous (Gambusia affinis) dan ikan kepala timah (Panchax panchax) merupakan ikan yang terbukti sebagai ikan pemakan jentik yang handal (Widyanto, Hernady, \& Abdullah, 2013).

Pencegahan dengan cara biologis merupakan cara yang ramah lingkungan. Penggunaan bahan kimia dalam jumlah besar dan secara terus menerus akan menimbulkan gangguan pada lingkungan karena terjadi penumpukan bahan kimia yang berlebihan. Sehubungan dengan hal itu, melakukan tindakan pencegahan secara biologis adalah cara yang tidak akan menimbulkan masalah pada lingkungan sekitar.

\section{KESIMPULAN}

Dari kegiatan PKMD tersebut, didapatkan kesimpulan bahwa materi tentang DBD bisa dipahami dengan baik oleh kader Posyandu Dahlia di Dusun Jetis, Desa Bakungan, Karangdowo, Klaten dengan melihat peningkatan nilai pada pretes dan postes. Dari angket kepuasan yang diisi oleh seluruh peserta, didapatkan hasil dengan kategori baik atau memuaskan. Selain itu, kader Posyandu Dahlia juga diharapkan bisa melakukan dan berbagi pengetahuan tentang upaya pencegahan DBD kepada masyarakat lain.

\section{SARAN}

Karena di tengah pendemi COVID-19 ini dengan gejala DBD yang hampir sama dengan COVID-19 maka tema kami telah terlaksana dengan baik. Diharapkan Kader 
posyandu dapat menindaklanjuti hasil edukasi dengan mengajarkan ke warga terkait budidaya tanaman, pemeliharaan ikan, pemakaian abate yang disarankan serta mengajarkan cara menjadi jumantik mandiri selama masa pandemi.

\section{UCAPAN TERIMAKASIH}

Atas terlaksananya acara PKMD 2020 di

Dusun Jetis, Desa Bakungan, kami mengucapkan terimakasih kepada:

1. Allah SWT yang telah atas limpahan karunia dan hidayah-Nya sehingga acara ini bisa terlaksana dengan baik

2. Pemerintah desa Bakungan yang telah mengizinkan untuk melaksanakan kegiatan penyuluhan ini

3. Kader Posyandu Dahlia dan masyarakat Dusun Jetis, Desa Bakungan, Karangdowo, Klaten

4. Semua pihak yang telah membantu pelaksanaan acara PKMD ini.

\section{REFERENSI}

Diba, F., \& Farkhan. (2017). Pilot Study: Efektifitas Penerapan Lembar Pemantauan Jentik Nyamuk Aedes Aegypti Secara Mandiri Di Desa Lampuja, Aceh Besar. Idea Nursing Journal, III, 63-72.

Dirjen Pencegahan dan Pengendalian Penyakit (2016). IMPLEMENTASI PSN 3M-PLUS dengan GERAKAN 1 RUMAH 1 JUMANTIK. Jakarta: Kementerian Kesehatan Republik Indonesia Direktorat Jenderal Pencegahan dan Pengendalian Penyakit.

Farasari, Rizqi; Muhammad Azinar . (2018). Model Buku Saku Dan Rapor $\begin{array}{llr}\text { Pemantauan Jentik } & \begin{array}{r}\text { Dalam } \\ \text { Perilaku }\end{array} \\ \text { Meningkatkan } & & \text { Sal }\end{array}$

Pemberantasan Sarang Nyamuk. Journal of Health Education , 110117.

Mubarokah, R. (2013). Upaya Peningkatan Angka Bebas Jentik Demam Berdarah Dengue Melalui Penggerakan Juru Pemantau Jentik di RW 1 Kelurahan Danyang Kecamatan Purwodadi Kabupaten Grobogan Tahun 2012. Semarang: UNNES.

Nazri, C. Hashim, A. Rodziah, I. \& Hasan, A. Y. (2013). Utilization of Geoinformation Tools for Dengue Control Management Strategy: a Case Study in Seberang Prai, Penang, Malaysia. International Journal of Remote Sensing Applications, 2-6.

Nisa, A. (2018). Korelasi Antara Faktor Curah Hujan Dengan Kejadian DBD Tahun 2010-2014 Di Kabupaten Karanganyar . Jurnal IKESMA, 2532.

Pongsilurang, CM., Sapulete, M. R., \& Kaunang, W. P. J. (2015). Pemetaan Kasus Demam Berdarah Dengue di Kota Manado. Jurnal Kedokteran Komunitas dan Tropik, 66-72.

Rahmatullah, W. (2018). Promosi Budidaya Tanaman Pengusir Nyamuk (Mosquito Epellent) Pada PKK Rt 31 Rw 07 Dolahan Kelurahan Purbayan Kotagede. jurnal ADIMAS, 24-29.

Widyanto, A., Hernady, S., \& Abdullah, S. (2013). Daya Predasi Berbagai Jenis Ikan Air Tawar Terhadap Larva Aedes Aegypti Sebagai Metode Pengendalian Biologi Terhadap Vektor Penyakit Demam Berdarah Dengue. Jurnal Poltekkes Kemenkes Semarang , 293-297.

[1] Zen, S., \& Noor, R. (2016). Inventarisasi Tanaman Yang Berpotensi Sebagai Bioinsektisida Nyamuk Aedes Aegypti Di Kota Metro Provinsi Bandar Lampung . Bioedukasi Universitas Muhammadiyah Metro, 139-143 